\title{
PERAN INTENSITAS INTERAKSI DENGAN TEMAN DI LINGKUNGAN PERGAULAN SEKOLAH TERHADAP SIKAP KONSUMTIF
}

\author{
Mahdalela \\ Universitas Gadjah Mada
}

\begin{abstract}
INTISARI
Penelitian ini bertujuan untuk mengetahui peran intensitas interaksi nomaja SMU dengan teman sekolah terhadap sikap konsumifnya, khususnya remaja SMU BCPKRII Yogyakanta yang berusia antara 15 tahun sampai 18 tahun. Siswa-siswi SMU BOPKRI I Yogyakana dipilih sebagai subjek penelitian dengan pertimbangan bahwa SMU BOPKRI I Yogyakarta terletak di pusat kota Yogyakarta yang dikelilingi oleh pusat-pusat hiburan maupun pusal pertokoan, sehingga memungkinkan siswa-siswinya lebih cepat terpengaruh dengan informasi yang ditawarkan para produsen. Jumlah subjek sebanyak 200 orang. Pengumpulan data dilakukan dengan angket. Data yang diperoleh dianalisis dengan analisis korelasional. Hasi analisis menunjukkan korelasi negatif ( $r=-0.115 ; p=0.053$ ). Peran intensitas interaksi terhadap sikap konsumtit tidak signifikan.
\end{abstract}

Kata Kuncl: Intensitas interaksi, sikap konsumtif, kelompok referensi konsep diri positif, konsep diri negatif

Mahdalela adalah alumnus Fakultas Psikologi UGM Yogyakarta.

\section{PENGANTAR}

Perkembangan zaman telah membawa implikasi pada perilaku membeli seseorang. Membanjirnya barang-barang di pasaran mempengaruhi sikap seseorang tertadap pembelian dan pemakaian barang. Pembelian suatu produk bukan lagi untuk memenuhi kebutuhan (need), melainkan karena keinginan (want).

Adanya kemajuan ini secara implisit menyebabkan has rat konsumtif dan daya beli juga bertambah. Apa yang dulu tidak dikenal, sekarang telah menjadi barang yang biasa. Gejala konsumtivisme yang terbawa oleh berhasilnya pembangunan juga menghasilkan kesenjangan antara bertambahnya 
barang k onsumsi dalam segala bentuk atau bertarnbah luasnya persepsi tentang kebutuhan dan daya untuk memenuhi kebutuhan tersebut. Kebiasaan dan gaya hidup juga berubah dalam waktu yang relatif singkat menuju ke arah semakin mewah dan berlebihan. Pola konsumsi seperti ini terjadi pada hampir semua lapisan masyarakat, meskipun dengan kadar yang berteda-beda. Hampir tidak ada golongan yang luput dari hal tersebut (Dahian, 1978).

Konsumen remaja mempunyai keinginan membeli yang tinggi, karena pada umumnya remaja mempunyai ciri khas dalam berpakaian, berdandan, gaya rambut, tingkah laku, kesenangan musik, dalam pertemuan dan pesta. Remaja ingin seialu berpenampilan yang dapat menarik perhatian orang lain terutama teman sebaya, sehingga remaja kebanyakan membelanjakan uangnya untuk keperluan tersebut (Monks, dkk. 1989).

Masa remaja merupakan masa transisi dari masa kanak-kanak menuju usia dewasa. Pada masa remaja individu mulai mengalami perubahan dalam sikap dan perilakunya sejajar dengan tingkat pertumbuhan fisiknya. Remaja sangat mudah dipengaruhi oleh faktor yang ada d luar dirinya seperti keluarga, lingkungan pergaulan, teman sebaya dan teman sekolah. Sifat-sifat seperti inilah yang mengakibatkan remaja danggap sebagai sasaran pasar yang paling menguntungkan. Sehubungan dengan itu, Yatman (1987) menganalisis keadaan di Indonesia dengan mengungkapkan pandangan bahwa remaja merupakan kelompok sasaran pasaran yang paling potensial.

Remaja, yang berada pada posisi transisi dalam perkembangan hidup manusia, mengalami berbagai perubahan, baik yang berkaitan dengan perubahan fisik, interaksi sosial ataupun pencarian identitas dirinya. Rernaja mutai mengarahkan geraknya menuju kelompok sebaya yang dianggap mem- punyai kesamaan pandangan. Kebutuhan untuk diterima kelompok sebaya sangat penting bagi remaja (Palmer dalam Mappiare, 1983). Dalam usahanya untuk dapat diterima kelompok, renaja harus membuat penampilannya sama dengan pola-pola dan ha rapan-harapan sesama remaja, sehingga perhatiannya seringkali difokuskan pada diri sendiri. Mereka biasanya mulai sadar akan penampilan dirinya penampilan wajah, pakaian, rambut dan penampilan fisik lainnya. Karena mereka berpendapat bahwa penampilan diri memainkan peranan penting dalam penerimaan sosialtentama penerimaan dari teman sebaya.

Berdasarkan hasil penelitian Glock (dalam Loudon dan Bitta, 1984), dikelahui bahwa konsumsi yang berlebihan sangat ditentukan oleh sikap mudah terpengaruh oleh kelompok referensi. Kekuatan pengaruh tersebut berkaitan dengan ciri sifat kepribadian yang dimiliki oleh masing-masing individu. Monks dkk.(1989) menyatakan bahwa remaja memiliki kontrol ekstemal lebih tinggi danipada kontrol intemal sehingga lebih peka terhadap pengaruh kelompok. Remaja mempunyai kepekaan terhadap apa yang sedang in, remaja mengikuti mode yang sediang beredar. Mode itu sendiri terus menuntut rasa tidak puas pada konsumen yang memakainya, sehingga mendorong konsumen untuk mengkonsumsinya karena takut ketinggalan. Kenyataan ini membuat remaja mempunyai pola konsumsi yang menunjukkan pada keeksklusivan, sifa! lebih mahal dan lebih mewah. Manifestasinya tampak pada penampilan remaja dengan mode yang mutakhir dan lekat dengan hasrat untuk memperoleh pengakuan dari teman-ternannya. Ketakutan remaja ketinggalan mode karena pengaruh teman-temannya dan ingin selaras (konform) dengan lingkungannya.

Arus konsumtivisme yang tel ah melanda kalangan remaja, menungut gaya hid up seperti ini merupakan cara paling tepat untuk 
dapat kut masuk ke dalam kelompok sosial yang diinginkan.

Berdasarkan kenyataan yang ada diketahui bahwa remaja semakin berlomba-lomba dengan gaya hidup mewah dan selału mengikuti mode yang yang sedang trend. Dengan gaya hidup ala modern remaja akan dipandang oleh teman-teman sebayanya sebagai sosok individu yang modem. Sehubungan dengan itu penulis menganggap perlunya diadakan penelitian apakah sikap konsumtif yang ada di kalangan remaja SMU dipengaruhi oleh intensitas interaksi dengan teman sekolah.

\section{DASARTEOR|}

Sikap konsumtif adalah sikap hidup di mana manusia dikendalikan oleh suatu keinginan untuk memenuhi hasrat kesenangan duniawi semata-mata (Grinder, 1978). Konsumtivisme adalah pola-pola konsumsi yang bersifat foya-foya, pemborosan, kepuasan yang dapat ditunda menjadi kepuasan yang harus segera dipenuhi (Lamarto, 1985). Sikap konsumtif menyebabkan seseorang selalu merasa tidak puas, tanpa peduli bagaimana cara mendapatkannya (Serviam, 1983).

Menurut Yayasan Lembaga Konsumen Indonesia, sikap konsumtif merupakan kecenderungan manusia untuk melakukan penggunaan konsumsi tiada batas. Manusia lebih mementingkan faktor keinginan daripada kebutuhan.

Faktor-faktor yang dapat mempengaruhi sikap konsumtif berkaitan dengan faktor yang mempengaruhi perilaku konsumen. Engel dkk (1973) mengatakan bahwa pada penelitian tentang konsumtivisme dapat digunakan pendekatan perilaku konsumen, antara lain:

Pertama, Faktor eksternal. Perilaku konsumen sangat dipengaruhi oleh bertagai lapisan masyarakat tempat orang tersebut lahir dan dibesarkan. Konsumen yang berasal dari lingkungan yang berbeda akan mempunyai penilaian, kebutuhan, pendapat, dan selera yang berbedabeda (Swastha dan Handoko, 1987). Faktor-faktor eksternal meliputi (a) kebudayaan, (b) kelas sosial, (c) kelompok sosial dan kelompok referensi (d) keluarga.

Kedua, Faktor internal, yang termasuk dalam faktor ini adalah (a). motivasi, (b). pengamatan dan belajar, (c). kepribadian dan konsepdiri.

Dari uraian di atas dapat disimpuikan bahwa sikap konsumtif pada remaja merupakan suatu kecenderungan bertindak dengan keinginan untuk membeli barangbarang yang sebenamya kurang atau tidak diperlukan, kecenderungan untuk mengikuti orang lain, manusia dikuasai deh has rat kesenangan materiat semata. Adanya sikap seperti ini membuat orang selalu merasa tidak puas jika barang yang diinginkannya belum dimitiki.

\section{INTERAKSI REMAJA DENGAN TEMAN SEKOLAH}

Interaksi remaja dengan teman sekolahnya merupakan suatu hubungan antara dua individu atau lebih individu manusia. Perilaku individu yang satu mempengaruhi, mengubah atau memperbaiki perilaku individu yang lain. tnteraksi remaja dengan teman sekolah senantiasa merupakan interaksi timbal balik saling mempengaruhi.

Kelompok sebaya, dalam hal ini ternan sekolah, sangat besar pengaruhnya terhadap proses sosjalisasi selama masa remaja. Kelompok teman sebaya tidak hanya berfungsi sebagai sumber pelindung perasaan, tetapi juga membuat acuan perilaku sosial yang dapat diterima dan mengharapkan agar anggota-anggota kelompoknya dapat menyesuaikan diri dengan acuan-acuan tersebut Kelompok merninta agar anggota-ang- 
gota setia pada kelompok dan terikat pada tujuan kelompok yang telah ditetapkan. Remaja harus menga dakan penyesuaian baru dengan meningkatnya pengaruh kelormpok sebaya, perubahan dakam perilaku sosial, pengelompokan sosial yang baru, nilai-nilai baru dalam dukungan dan penolakan sosial (Hurlock, 1993).

Remaja lebih banyak berada di luar rumah bersama teman-teman sebaya sebagai kelompok. Sebagai konsekuensinya pengaruh teman sebaya pada sikap. pembicaraan, minat penampilan dan perilaku remaja lebih besar daripada pengaruh keluarga. Misainya, sebagian besar remaja mengetahui bahwa bila mereka memakai mode pakaian yang sama dengan anggota kelompok populer, maka kesempatan baginya untuk diterima kelompok menjad lebh besar, maka remaja cenderung mengkutinya tanpa mempedulkan perasaan mercka sendri (Hurlock, 1993).

Kełompoksebayamerupakandunianyata kawula muda, yang menyiapkan panggung supaya individu dapat menguji diri sendiri dan orang lain. Kelompok sebaya merupakan wadah individu dinilai oleh orang lain yang sejajar dengan dirinya dan yang tidak dapat memaksakan sanksi-sanksi dunia dewasa yang justru ingin dihindari. Ternan sebaya merupakan suatu dunia tempat kawula muda dapat memberikan sosialisasi dalarn suasana di mana nilai-nilai yang berlaku bukanlah nillai-nilai yang ditetapkan olch orang dewasa, melainkan oleh temanteman seusianya (Hurfock, 1993).

Jadi di dalam masyarakat sebaya, dalam hal ini adalah teman sekolah inilah remaja memperoleh dukungan untuk emansipasi dan d situ puia individu dapat menemukan dunia yang memungkinkannya bertindak sebagai pemimpin apabila ia mampu melakukannya. Kecuali itu kelompok sebaya merupakan hiburan utama bagi incividu yang berusia belasan tahun. Berdasarkan alasan tersebut tampak bahwa kepentingan vitak masa remaja adalah kelompok sebaya, terdri dari anggota-anggota tertentu dari temantemannya yang dapat menerimanya dan kepadanya individu bergantung (Hurfock, 1993).

Uraian d atas dapat disimpulkan bahwa interaksi remaja dengan teman sekolah merupakan hubungan antara individu satu dengan individu satu dengan individu lain atau hubungan individu dengan kelompok terjadi saling mempengaruhi satu sama lain dalam pikiran, perasaan, sikap dan perilaku. Masing-masing yang tergabung dalarn kelompok tersebut harus menyesuaikan diri dengan norma-norma yang berlaku dalam kelompoknya.Dengan demikian remaja tersebut diakui keberadaannya.

Penyesuaian diri yang dilakukan remaja tehadap teman sekolah berlangsung karena adanya kontak sosial yang berlangsung terusmenerus dalam frekuensi sering untuk waktu yang relatif panjang. Selain itu proses penyesuaian diri melibatkan bermacam-macam bentuk kegiatan atau peristiwa sehing. ga menimbulkan hubungan yang crat. Peneittian ini akan mengukur aspek-aspek yang merupakan indikator intensitas interaksi remaja dengan teman sekolahnya. Kegiatan atau aktivitas apa saja yang melibatkan individu berinteraksi dengan teman sekolah dan seberapa jauh pengaruh dari teman sekolah dalam sikap dan perilakunya seharihari.

Beberapa di antara bentuk interaksi dengan teman sekolah yang dijabarkan di atas, diambil menjadi aspek pembentuk alat pengukur intensitas interaksi dengan teman sekolah yang digunakan dalam penelitian ini. Aspek tersebut adalah: kontak sosiak secara langsung, frekuensi/kekerapan, wakis relatif panjang, berbagai aktivitas/kegiatan. Dengan pertimbangan bahwa hal tersebut ditemukan dalam interaksi remaja setiaphari. 


\section{PERAN INTERAKSI REMAJA DENGAN TEMAN SEKOLAH TERHADAP SIKAP KONSUMTIF}

Kuatnya pengaruh interaksi dengan teman sekolah sangat menentukan sikap konsumtif di kalangan remaja. Masing-masing individu dalam kelompok akan selalu mendapatkan informasi tentang model-model pakaian, gaya rambut, film dan barang-barang lain yang sedang in. Kondisi ini menimbulkan remaja berlomba-lomba untuk tampil modern agar disukai keberadaannya di tengah teman-teman sebayanya.

Remaja pada masa transisinya, memilki kondisi emosional yang masih labil, sehingga mudah dipengaruhi oleh kelompoknya. Kebanyakan remaja menganggap bathwa penampilan dan gaya hidup mewah merupakan simbol status lebih tinggi dalam kelompoknya. Hal ini mengakibatkan adanya sikap untuk bersaing dalam penampilan dirinya, seperti pakaian, sepatu, gaya rambut dan barang-barang mewah lainnya (Hurlock. 1993).

Pencarian identitas dir serta pengakuan dari lingkungan sosialnya. didukung oteh kondisi psikis yang belum matang, menyebabkan remaja memiliki kecenderungan lebih mudah terpengaruh oleh faktor-faktor eksternal seperti kelompok sebaya atau dukungan ekstemal lainnya. Remaja kurang memiliki keyakinan pada dri sendiri, sehingga apa yang baik menurut orang lain. juga baik bagi dirinya tanpa pertimbangan mendalam. Kecenderungan tersebut merupakan usaha konformdengan lingkungan sosial, khususnya lingkungan remaja.

Berdasarkan hasil penelitian Glock (dalam Loudon dan Bitta, 1984) diketahui bahwa konsumsi yang berlebihan sangat ditentukan oleh sikap mudah terpengaruh oleh kelompok referensi berkaitan dengan ciri sifat kepribadian yang dimiliki oleh masing-masing individu. Monks dkk (1989) menyatakan bahwa remaja memiliki kontrol eksternal lebih tinggi daripada kontrol internalnya. sehingga remaja lebih peka terhadap pengaruh kelompoknya. Rernaja yang berada dalam kelompok yang sama dapat menyebabkan mereka mempunyai prinsip-prinsip dasar yang sama dalam sikap konsumtifnya. Sikap konsumtif yang merupakan sikap yang dihasilkan atas pertimbangan yang tidak rasional mempunyai kemungkinan dilakukan oleh rernaja, sebagai salah satu usaha mendapatkan penghargaan dari lingkungan ternan sekolah.

Uraian di atas dapat disimpulkan bahwa intensitas interaksi dengan ternan sekolah merupakan salah satu faktor yang berperanan penting terhadap pembentukan sikap konsumtif pada remaja. Adanya interaksi yang dekat dan berlangsung terus-menerus dalam frekuensi interaksi relatif sening menjadikan remaja saling mempengaruhi dan menyesuaikan diri satu sama lain, sehingga terbentuk sikap dan perilaku yang sama dalam kelompok tersebut. Demikian halnya dengan sikap konsumtif yang terjadi pada remaja tidak lepas dari pengaruh interaksi dengan teman sekolahnya.

\section{HIPOTESIS}

Berdasarkan teon-teori maupun hasli penelitian yang telah didapatkan di atas, maka penulis mengajukan hipotesis: semakin ting$g$ intensitas interaksi dengan teman sekolah akan diikuti oleh semakin tinggi sikap konsumtif pada remaja SMA.

\section{MET ODE}

Yang menjadi variabel penelitian adalah intensitas interaksi dengan teman sekolah dan sikap Konsumtif. Intensitas interaksi dengan teman sekolah didefinisikan tingginya skor yang diperoleh dari angket intensitas interaksi yang terjadi dengan teman sekolah. 
Sikap konsumtif adalah sikap yang mengarah pada pola hidup dengan keinginan untuk membeli barang-barang yang kurang/ tidak diperlukan dan perasaan tidak puas selalu menyertai bila barang-barang yang diinginkan belum dimiliki. Sikap konsumbif akan diungkap dengan angket pengukur sikap konsumtif pada remaja Makin tinggi nilai skor yang diperoleh makin tinggi sikap konsumtif.

Subjek penelitian ini adalah 200 siswasiswi SMU BOPKRI I Daerah Istimewa Yogyakarta yang merupakan kelompok remaja pertengahan yang berusia antara 15 tahun sampai dengan 18 tahun.

Selanjutnya akan diterangkan tentang metode pengumulan data. Intensitas interaksi dengan teman sekolah diukur melalui skala yang dibuat oleh peneliti. Skala terdiri dari 55 butir pernyataan yang merupakan manifestasi tiga aspek yang menentukan tingginya intensitas interaksi ternan sekolah, yaitu (1) kontak sosial secara langsung. (2) frekuensi (kekerapan), (3) beragai aktivitas.

Skaka berbentuk model skala Likert dengan lima alternatif jawaban, yaitu sangat sesuai (SS), sesuai (S), tidak dapat menentukan (E), tidak sesuai (TS) dan sangat tidak sesuai (STS). Pemberian skornya tergantung dari favorable atau tidaknya suatu butir. Skor jawaban bergerak dari nilai 5 sampai 1 pada butir yang favorable dan 1 sampai 5 pada butir unfavorable.

Seleksi butir dilakukan dengan analisis internal consistency. (Azwar, 1988).

Dal am skala ini, butir yang dapat dipakai adalah butir yang memiliki koefisien (nilai $\mathrm{rbl}$ ) antara 0,207 hingga 0,714. Tenyata dari 80 butir, yang layak dipakai berjumlan 55 butir. Koefisien reliabilitas skala intensitas interaksi dengan teman sekolah sebesar 0,928 :

Sikap Konsumtif diukur dengan skala sikap konsumtif. Skala ini disusun oleh Wilujeng (1992), mengukur sikap konsumtif
(Swastha dan Handoko, 1987), yang mengarah pada pola hidup dengan keinginan untuk membeli barang-barang yang kurang/ tidak diperlukan dan perasaan tidak puas selalu menyertai bila barang-barang yang diinginkan belum dimiliki.

Skala ini terdiri dari lima alternatif jawaban, yaitu sangat setuju (SS), setuju (S), tidak dapat menentukan (E), tidak setuju (TS) dan sangat tidak setuju (STS).

Pemberian skornya tergantung dari favorable atau unfavorable suatu butir. Skor jawaban bergerak dari nilai 5 sampai 1. Pada butir favorabie dan nilai 1 sampai 5 pada butir yang unfavorable.

Seleksi butir, validitas dan reliabilitas dilaksanakan seperti skala intensitas interaksi dengan teman sebaya 1992. Hasil seleksi butir menunjukkan terdapat 45 butir yang memiliki koefisien korelasi antara 0.221 hingga 0.866 . Koefisien reliabilitas 0.935 .

\section{HASIL}

Gambaran umum data intensitas interaksi dengan teman di lingkungan pergaulan sekolah dan data sikap konsumtil disajikan secara deskriptif pada Tabel 1.

Uji korelasi antara intensitas interaksi dengan teman sekolah dengan sikap konsumtif menunjukkan korelasi negatif $(r=-$ $0.115 ; p=0.053$ ). Hubungan intensitas interaksi dan sikap konsumtif tidak signifikan. Dengan demikian hipotesis ditolak.

Hasil analisis tambahan yang menunjukkan indikator sikap konsumtif pada subjek penelitian disajikan secara deskriptif pada Tabel 2.

Hasil analisis tambahan menunjukkan dari 200 subjek yang memiliki sikap konsumtif adalah sebagai berikut:

1. Belanja kebutuhan penunjang penampilan (pakaian, sepatu, tas, parfum, asesoris) dengan frekuensi lebih dari $5 \times 1$ bulan sebanyak $1.5 \%$. 


\section{Tabel1 \\ Statistik Deskriptif \\ Intensitas interaksi dan Sikap Konsumil \\ $(n=200)$}

\begin{tabular}{|c|c|c|c|c|c|c|c|}
\hline \multirow{2}{*}{ Variabel } & \multicolumn{3}{|c|}{ Skor yang dimungkinkan } & \multicolumn{4}{|c|}{ Skor yang diperoleh } \\
\cline { 2 - 8 } & Min & Maks & Mean & Min & Maks & Mean & SD \\
\hline $\begin{array}{c}\text { Intensitas } \\
\text { interaksi }\end{array}$ & 55 & 275 & 165 & 147 & 290 & 212 & 22.89 \\
\hline $\begin{array}{c}\text { Skkap } \\
\text { konsumtif }\end{array}$ & 45 & 225 & 135 & 53 & 152 & 91.22 & 18.08 \\
\hline
\end{tabular}

Tabel2

Hash analis is tambehan Sikap Konsumtf

$(n=200)$

\begin{tabular}{|c|l|l|c|}
\hline Butir & \multicolumn{1}{|c|}{ Keterangan } & \multicolumn{1}{|c|}{ Frekuensi } & Persentase \\
\hline 1. & $\begin{array}{l}\text { Belanja kebutuhan } \\
\text { penunjang penampilan }\end{array}$ & df atas $5 \times 1$ bulan & 1.5 \\
\hline 2. & Nonton di bioskop & Lebih dari $4 \times 1$ bulan & 7 \\
\hline 3. & Makan di restoran & Lebih dari $4 \times 1$ bulan & 11.5 \\
\hline 4. & Ke diskotik & Lebih dari $4 \times 1$ bulan & 3.5 \\
\hline 5. & Tabungan & $\begin{array}{l}\text { Lebihdari Rp. } 50.000 \\
\text { perbulan. }\end{array}$ & 9.5 \\
\hline
\end{tabular}


2. Nonton di bioskop lebih dari $4 \times 1$ bulan sebanyak $7 \%$.

3. Makan di restoran lebih dari $4 \times 1$ bulan sebanyak $11.5 \%$.

4. Mengunjungi diskotik lebih dari $4 \times 1$ bulan sebanyak $3.5 \%$.

5. Tabungan lebih dari Fp 50.000 per bulan (berarti tidak konsumtif sebanyak $9.5 \%$.

\section{DISKuSI}

Hasil analisis menunjukkan bahwa hipotesis ditolak. Ada dua kemungkinan sehubungan dengan tidak tampaknya hubungan antara intensitas interaksi dengan teman di lingkungan pergaulan sekolah dengan sikap konsumtif pada remaja SMU pada penelitian ini, yaitu: (1) subjek penelitian ini tidak memiliki sikap konsumtif yang tinggi; (2) variabel-variabel lain yang berperan terhadap sikap konsumtif tidak ikut diteliti.

Pertama, subjek penelitian tidak memilikj skap konsumtif yang tinggi. Hal ini dapat disebabkan gaya hidup lingkungan pergaulan subjek sehari-hari tunt mempengaruhi sikap subjek. Subjek yang digunakan pada penelitian ini adalah remaja yang dipengaruhi oleh pola hidup di kota Yogyakarta pada umumnya mempunyai prinsip gaya hidup sederhana. Gaya hidup sederhana menyebabkan orang puas dengan apa yang dimilikinya. Mereka berprinsip untuk tidak terlalu berlebihan dalam materi, sehingga apa yang dimilikiny a adalah hal yang perlu disyukuri, diterima dengan senang hati, sehingga mereka tiak memandang perlu berlomba-lomba dalam mengejar kesenangan hidup.

Penelitian ini menunjukkan bahwa sebagian besar subjek tidak memiliki kecenderungan sikap konsumtif yang tinggi. Hal ini dapat dilihat pada mean skala sikap konsumtif dari data yang diperoleh $=91.22$, sedangkan mean dimungkinkan $=135$. Tampak bahwa mean hasil penelitian lebih rendah dari skor mean yang dimungkinkan. Sikap konsumtif rendah pada subjek didukung pula oleh hasil analisis tambahan dari persentase jumlah subjek yang tergolong memiliki sikap konsumtif rendah. Menabung lebih dari Fip 50.000 per bulan berarti tidak konsumtif.

Kedva, variabel-variabel lain yang berperan terhadap sikap konsumtif. Penelitian ini tidak mengikutsertakan variabel-variabel lain yang uga berkaitan dalam pembentukan sikap konsumtif pada remaja SMU seperti penghasilan orang tua, uang saku, gaya hidup keluarga subjek, tempat tinggal (bersama orang tua dengan subjek yang tinggal di pondokan) dan konsepdiri.

Gaya hidup dalam keluarga akan mempengaruhi pembentukan sikap dan perilaku manusia terutama yang ditanamkan oleh orangtua, akan dianut oleh anak, karena anak pertama kali mengenal lingkungan so sial adalah lingkungan keluarganya sendiri, dalam hal ini adalah orangtua sangat mendominasi dalam mempengaruhi sikap hidup anak. Oleh karena itu remaja cenderung mempunyai sikap hidup yang sama dengan orang tua mereka (Swastha \& Handoko, 1987 ).

Tiap orang mempunyai konsep diri yang berbeda-beda yang menyebabkan perbedaan dalam menanggapi lingkungan d mana ia berada. Orang yang mempunyai konsep diri positif selalu mempertimbangkan motivasi, tujuan dan kemampuannya sebelum membuat suatu/keputusan, karena mereka memiliki orientasi pada kontrol internal, artinya individu memiliki kendali yang kuat dalam menanggapi pengaruh luaryang menentukan besar kecilnya perubahan ataı pembentukan sikap. Mereka tidak mudah terpengaruh oleh pengaruh ekstemal seperti media massa ataupun pengaruh interpersonal dalam interaksi sosial. Sebaliknya orang yang mempunyai konsep diri negatif lebih berorientasi pada kontrol ekstemal (Witkins 
dalam Burns, 1979). Mereka lebih mudah dipengaruhi oleh faktor dari tuar, karena mereka kurang yakin terhadap dirinya sendiri sehingga dalam mengambil suaku keputusan mereka cendenung mengandalkan opini orang tain. Hasil penelitian Humprey (dalam Bums, 1979) menyimpulkan bahwa remaja yang memiliki konsep diri negatif cenderung lebih tertarik untuk membeli pakaian dan sangat memperhatikan pakaian daripada remaja yang memiliki konsep diri positif. Remaja yang memiliki konsep diri negatif menggunakan pakaian sebagai ekspresi diri, menarik perhatian dan memperolah penghargaan dari orang lain. Remaja yang memiliki konsep diri negatif menunjukkan penolakan diri, khususnya berkaitan dengan perubahan fisik yang terjadi pada masa remaja. Penolakan diri ini menyebabkan remaja melakukan berbagai usaha untuk memperoleh penghargaan dari orang lain. Hal ini dapat ditinjau dari perbedaan penerimaan diri terutama membuat penampilannya sedemikian rupa sehingga dapat menarik perhatian orang lain. Usaha tersebut merupakan sarana untuk memperoieh penghargaan dari orang lain karena mereka memiliki konsep diri positif tidak perfu berusaha menarik perhatian dengan penampilan yang berlebihan-lebihan karena mereka telah memiliki penerimaan diri dengan baik.

\section{PENUTUP}

Berdasarkan hasil dan pembahasan dalam penelitian ini, dapat disimpulkan bahwa interaksi dengan teman sekolah temaja SMU tidak memiliki peran yang meyakinkan terhadap sikap konsumtif. Diduga bahwa terdapat variabel-variabel lain yang berperan terhadap sikap konsumtif, antara lain variabel internal seperti konsep diri, maupun variabel eksternal seperti penghasilan orang tua, uang saku dan gaya hidup keluarga.
Selanjutnya ada beberapa saran yang perfu peneliti sampaikan. Pertama, penelitian selanjutnya agar menyertakan variabelvariabel lain yang mungkin mempengaruhi sikap konsumtif, baik variabel internal seperti konsep diri maupun variabel ekstemal lainnya seperti penghasilan orangtua, uang saku, gaya hid up kelıarga. Sebaiknya diteliti juga perbedaan sikap konsumtif remaja yang tinggal di perkotaan dengan remaja yang tinggal di luar kota.

Kedua, bagi siswa-siswi SMU supaya mempertahankan sikap konsumtif yang rendah dan intensitas interaksi yang tinggi seperti hasit penelitian ini.

\section{DAFTAR PUSTAKA}

Azwar, S. 1988. Sikap Manusia Teori dan Pengukurannya, Yogyakarta: Liberty.

Azwar, S. 1992. Reliabilitas dan Validitas. Yogyakarta: Sigma Alpha.

Burns, A.B. 1979. The Seff Concept in The Measurement, Development and Behavior, New York: Logman Inc.

Cathoun, J.F. \& Acocelto, J.R. 1990. Psychology of Adjustment and Human Relationships. Third Edition. New York: Mc Graw - Hill Publishing Company.

Conger, J.J. 1977. Adolescence and Youth Psychological Development in A Changing Word New York: Harper and Row.

Dahlan, A.M. 1978. Sosialisasi Pola Hidup Sedehana. MajalahPrisma, 10, 11-15.

Engel, J.F. Kollat, D.T, \& Blackwell, A.D. 1973. Consumer Behavior. Second Edition. New York: Holt Rinehart and Winston, Inc.

Gerungan, R.E. 1978. Adolesence. New York: John Wiley and Sons. 
Hadi, S. 1984. Metodologi Research II. Yogyakarta: Yayasan Penerbit Fakultas Psikologi UGM.

Hadi, S. 1992. Analisis Regresi, Yogyakarta: Andi Offset.

Hurtock E.B. 1993. Psikologi Perkembangan Suatu Pendekatan Sepanjang Rentang Kehidupan (terjemahan). Edisi 5. Jakarta: Erlangga.

Jersild, A.T. 1965. The Psychology of Adolescence. Second Edition. New York: The Macmillan Company.

Lamarto, Y. 1995. Prinsip Pemasaran. Jakarta: Erlangga.

Littler, M.B. \& J.B. Eicher. 1973. Clotching Opinion and The Social Acceptance Ptocess among Adolescents. Adolescence, 8, 197-212.

Loudon, D.L. \& Bitta, Della, A.J. 1984 Consumer Behavior. Second Edition. New York: Mc Graw Hill Book Company.

Mappiere, A 1983. Psikologi Remaja Surabaya: Usaha Nasional.

Mar'at 1981 . Sikap ManusiaP erubahan serta Pengukurannya. Edisi 2. Jakarta: Ghalia Indonesia.

Monks, FJ. Knoers, A.M.P. \& Haditono, S.R. 1989. Psikologi Perkembangan Pengantar dalam Berbagai Bagiannya. Yogyakarta: Gadjah Mada University Press.
Musa, K.E, \& Roach, M.E. 1973. Adolescent Appearence and Seff Concept, Adolescence, 8, 385-393.

Moschis, G.P. \& Churchill, G.A. 1979. An Analysis of the Adolescence. Journal of Marketing, 43, 137-146.

Nashori, F. 1991. Konsumtivisme Masyarakat Indonesia. Majałah Psikomedia. Edisi 7.

Newcomb, T.C. 1985 (tejemahan). Psikologi Sosial. Bandung: Diponegoro.

Sears, D.O. Freedman, J.L, \& Peplau, L.A. 1992. Psik ologiSosial(tejemahan), Jilid 1. Jakarta: Ertangga.

Serviam, 1983. Konsumerisme: Perlu atas Malu Jakarta: Sinar Harapan.

Swastha, B. \& Handoko, H. 1987. Manajemen Pemasaran: Analisis Perilaku Konsumen. Yogyakarta: Liberty.

Wilujeng, H.D. 1982. Hubungan Konsep Diri dan Sikap Konsumtif Pada Remaja. Skripsi. (tidak diterbitkan). Yogyakarta: Fakultas Psikologi UGM.

Wirawan, S. 1976. Pengantar limu Psikologi. Cetakan \ Jakarta: Bulan Bintang.

Yatman, D. 1987. Remaja Incaran Iklan. Ke daulatan Rakyat. 10 September. Yogyakarta 